\title{
Pengaruh Penggunaan Buku Cerita Bergambar Terhadap Kemampuan Berbicara Anak
}

\author{
Eka Mei Ratnasari, Enny Zubaidah \\ eka.mei2016@student.uny.ac.id, enny_zubaidah@yahoo.com \\ Universitas Negeri Yogyakarta
}

The Influence Of Picture Book Towards Preschool Children's Speaking Ability

\begin{abstract}
The development of speaking ability for children is very important so that children could adapt and socialize with friends. This research aimed to determine the influence of picture book on children speaking ability aged of 4-5 years. The type of the research was quasi-experiment. The subjects of this study were the children of group A in Pringwulung kindergarten Yogyakarta, Indonesia. The data collection used an observation sheet, and then analyzed using the t-test through SPSS 16 program to see the differences in speaking ability between the two groups. The result of the research was that there is a significant influence on the improvement of children's speaking ability through picture book of preschool children in Pringwulung kindergarten Yogyakarta. The recommendations of this research can be used by teachers, parents, education practitioners in order to provide an optimal stimulation to the development of children's speaking ability.
\end{abstract}

Keywords: Speaking Ability, Picture Book, Preschool Children

$\begin{array}{lcc}\text { Article Info } & \\ \text { Received date: } 28 \text { Juli } 2019 & \text { Revised date: } 5 \text { Agustus } 2019 \quad \text { Accepted date: } 20 \text { September } 2019\end{array}$

\section{PENDAHULUAN}

Berbicara adalah aspek penting dalam kehidupan manusia. Semenjak seorang bayi dilahirkan, ia sudah belajar menyuarakan lambang-lambang bunyi bicara melalui tangisan untuk berkomunikasi dengan lingkungannya. Hurlock (1978: 176) mengatakan bahwa kemampuan bicara menjadi kebutuhan penting dalam kehidupan anak, kebutuhan itu adalah untuk menjadi bagian dalam kelompok sosial. Saat anak belum lancar dalam berbicara, anak menggunakan cara lain untuk berkomunikasi dengan anggota kelompok sosial, tetapi peran yang diberikan anak dalam kelompok tersebut akan kecil. Pengembangan bicara sangat penting dan diperlukan anak untuk memperlancar kemampuan bicara. Oleh sebab itu, kemampuan berbicara anak perlu distimulus dan dilatih secara berkesinambungan. Penggunaan media merupakan hal yang efektif dalam membantu perkembangan kemampuan anak. Buku cerita bergambar merupakan pilihan yang baik dalam mengembangkan kemampuan bahasa anak. Guru harus memahami bahwa pada saat membacakan buku cerita bergambar dapat membantu anak membangun kosakata, kesadaran fonologi, dan mengembangkan pengenalan huruf (Machado, 2013: 252). Lenhart, et al. (2017: 1) mengemukakan pendapat serupa yaitu membacakan buku cerita bergambar secara bersamasama dapat memberikan intervensi dalam pengembangan kosakata anak.

Kegiatan observasi dilakukan di TK-ABA Pringwulung Yogyakarta, hasilnya menunjukkan bahwa pengembangan kegiatan yang menggali kemampuan berbicara sering ditinggalkan. Kebanyakan pendidik berfokus pada kemampuan kognitif seperti menghitung, mengenal huruf, membaca dan menulis serta pengggunaan lembar kerja anak. Hal ini terjadi disebabkan oleh tuntutan orangtua yang mengharapkan anaknya sudah dapat membaca dan menulis ketika memasuki sekolah dasar (SD). Terdapat kekhawatiran orangtua jika anaknya tidak dapat mengikuti pembelajaran di sekolah. Fenomena ini tidak hanya terjadi di TK yang berada di Yogyakarta saja, melainkan terjadi di wilayah lainnya pula. Fenomena ini di dukung hasil penelitian yang dilakukan oleh Istiyani (2013: 1) tentang orangtua dan lembaga pendidikan di kabupaten Pekalongan mengikutsertakan anak pada kegiatan les privat untuk meningkatkan kemampuan membaca, menulis dan berhitung (calistung) bahkan kegiatan ini sudah diikuti oleh anak sejak berada di usia 4 sampai 5 tahun. berdasarkan observasi yang telah dijabarkan sebelumnya, terdapat kondisi dimana anak tidak mampu mengungkapkan pendapatnya, hal 
ini tentu bertolak belakang dengan Peraturan Menteri Nomor 137 tahun 2014 tentang Tingkat Pencapaian Perkembangan Anak pada usia 4 sampai 5 tahun tentang mengutarakan pendapat kepada orang lain. Selama ini, guru menggali potensi bicara anak melalui kegiatan tanya jawab. Pada saat kegiatan tersebut, anak masih pasif dalam bicara, kurang berani dan tidak percaya diri dalam menyampaikan pendapat kepada orang lain, serta terdapat sebagian anak yang bicaranya belum jelas.

Media pembelajaran menjadi salah satu faktor yang menyumbangkan suksesnya sebuah kegiatan pembelajaran. Tujuan dari penggunaan media adalah untuk membantu mempermudah pemahaman anak. Anak yang berada pada usia 4 tahun belum mampu memahami isi pembelajaran yang disampaikan hanya dalam bentuk verbal. Penyampaian pembelajaran tersebut harus diimbangi dengan bantuan media untuk memperjelas tujuan yang akan disampaikan kepada anak. Hasil temuan tentang kemampuan bahasa anak di TK menunjukkan kurang adanya dukungan media yang digunakan sebagai alat peraga dalam proses pembelajaran bahasa. Sebagian besar media yang ada untuk meningkatkan perkembangan kemampuan motorik kasar dan halus anak, perkembangan kognitif, dan pajanganpajangan. Media yang paling ramah untuk keluarga khususnya anak adalah buku. Materi yang terdapat dalam buku disesuaikan dengan tingkatan usia anak. Penggunaan media dalam hal ini buku cerita bergambar tidak dipergunakan sebagai media dalam pembelajaran di sekolah. Guru menjelaskan bahwa jumlah ketersedian buku cerita bergambar masih minim, selain itu buku yang ada merupakan bukubuku terbitan lama. Serta tidak adanya waktu khusus bagi anak untuk membaca buku bersama guru di sekolah. Guru memberikan majalah anak berupa majalah CEPPI (cepat pintar untuk TK) yang berasal dari IGTKI, biasanya majalah ini diberikan dalam rentang waktu satu bulan sekali. Majalah tersebut diberikan pada anak kemudian guru memberikan instruksi agar majalahnya dibaca di rumah. Sedangkan di sekolah, guru menggunakan kegiatan bercerita tanpa menggunakan media dan tanya jawab. Media yang terdapat di sekolah yakni pajanan (gambar buah, angka), balok, dakon, dan playdough. Media merupakan grafik, fotografi, elektronik, alat-alat mekanik untuk menyajikan, memproses, dan mejelaskan informasi secara lisan atau visual. Media dipandang sebagai alat bantu bagi seorang guru untuk menunjang kegiatan pembelajaran yang dilakukan di kelas (Nugraha, R. G. A. (2017, 95).

Berdasarkan uraian yang telah dipaparkan, peneliti mengangkat permasalahan yang berkaitan dengan proses pembelajaran untuk mengetahui pengaruh penggunaan media buku cerita bergambar terhadap kemampuan berbicara anak usia 4-5 tahun. Hasil dari penelitian ini diharapkan dapat memberikan kontribusi bagi orangtua, guru, dan akademisi khususnya dalam perkembangan kemampuan bahasa anak.

\section{KAJIAN PUSTAKA}

\section{Berbicara}

Manusia lebih banyak menggunakan bahasa lisan dalam kehidupan sehari-hari untuk berkomunikasi dengan orang disekitarnya. Oleh sebab itu, kemampuan berbicara perlu distimulasi sejak usia dini agar anak mudah berkomunikasi dengan lingkungannya. Pemaparan tersebut didukung oleh pendapat Vygotsky (1978: 25) yang mengemukakan bahwa sebelum menguasai tingkah lakunya sendiri, anak mulai menguasai lingkungannya dengan bantuan kemampuan bicara. Para ahli memaparkan bahwa anak usia dini berada pada masa golden age, ini menjadi waktu yang sangat baik dalam menstimulasi berbagai macam aspek kemampuan, salah satunya yaitu bicara. Hurlock (1980: 112) menyebutkan bahwa pada awal masa kanak-kanak adalah saat berkembang pesatnya penguasaan tugas pokok dalam belajar bicara, yaitu dalam menambah kosakata, menguasai pengucapan kata dan menggabungkan kata menjadi sebuah kalimat. Awalnya pembicaraan anak bersifat egosentris, tetapi saat anak mulai menjelang akhir dari masa kanak-kanak awal maka mulailah pembicaraan yang bersifat sosial dan berbicara tentang sesuatu yang ada disekitarnya.

Berbicara membantu anak dalam membangun hubungan sosial sehingga memberikan kesempatan bagi persahabatan, empati dan berbagi emosi. Mart (2012: 91) mengemukakan bahwa kemampuan berbicara dapat berupa mengekspresikan atau bertukar pikiran. Jalongo (2007: 106) menjelaskan berbicara adalah ungkapan ekspresi dari bahasa yang dikeluarkan melalui mulut atau secara lisan. Bicara mengambil peran penting dalam berinteraksi dan bersosialisasi. Pada masa kanakkanak kemampuan bicara anak terus berkembang. Gnjatovic (2015: 85) mengemukakan teori Vygotsky tentang kemampuan bicara pada orang lain di mulai dengan satu kata menuju kalimat yang lebih 
bermakna. Bicara tidak hanya melibatkan koordinasi kumpulan otot mekanisme suara yang berbeda, tetapi juga mempunyai aspek mental yakni kemampuan mengkaitkan arti dengan bunyi yang dihasilkan.

Anak belajar berbicara dengan baik agar dapat bergaul dan mudah dipahami oleh teman sebayanya serta orang disekitarnya. Efrizal (2012: 127) mengemukakan bahwa berbicara adalah salah satu cara untuk mengkomunikasikan gagasan dan menyampaikannya secara lisan. Zainatuddar (2015: 446) menjelaskan bahwa berbicara adalah sebuah proses penyampaian maksud kepada orang lain dalam berbagai konteks. Komunikasi yang dilakukan anak akan membangun hubungan sosial yang baik dengan temannya. Lingkungan menjadi hal penting untuk mengembangkan kemampuan berbicara, yakni peran teman sebaya serta hubungan antara orangtua dan anak (Ramirez-Esparza et al., 2014: 880). Johnston (2010: 93) mengemukakan bahwa berkomunikasi dan saling membantu dapat membuat anak membangun hubungan sosial yang dapat memberi kesempatan pertemanan, empati dan berbagi emosi.

Berbicara merupakan cara berkomunikasi kepada sesama. Ruampol \& Wasupokin (2014: 2319) memaparkan bahwa berbicara adalah proses interaksi dalam membangun arti yang melibatkan produksi dan penerimaan serta memproses informasi. Berbicara dapat diartikan sebagai suatu penyampaian maksud, maksud tersebut dapat berupa ide/gagasan, pikiran, maupun perasaan seseorang kepada orang lain dengan menggunakan bahasa lisan sehingga maksud tersebut dapat dipahami oleh orang lain (Abbas, 2006: 83). Kayi (2006: 1) berpendapat bahwa berbicara adalah proses membangun dan berbagi makna melalui penggunaan simbol secara verbal dan non-verbal, dalam berbagai macam konteks. Pendapat serupa mengungkapkan bahwa berbicara adalah sarana berkomunikasi secara verbal, cara berkomunikasi lainnya termasuk namun tidak terbatas pada menulis, menggambar dan simbol (Owens, 2012: 6). Hurlock (1978: 176) berpendapat bahwa bicara adalah bentuk bahasa yang menggunakan artikulasi ataupun kata-kata yang digunakan dalam menyampaikan maksud, sebab bicara merupakan bentuk komunikasi yang paling efektif dan penting serta paling luas penggunaannya. Bicara merupakan proses pengeluaran kata-kata yang memiliki arti.

Berdasarkan beberapa pendapat yang telah dipaparkan, dapat disimpulkan bahwa kemampuan berbicara adalah kecakapan bentuk komunikasi secara lisan yang berfungsi untuk menyampaikan maksud ataupun informasi sehingga orang lain dapat memahami apa yang di sampaikan. Bahasa lisan lebih banyak digunakan dalam kehidupan sehari-hari untuk berkomunikasi dengan orang disekitarnya. Komunikasi yang baik dapat membangun hubungan sosial pada sesama dan lingkungan. Salah satu media dalam pembelajaran bagi anak usia dini dapat menggunakan buku cerita bergambar. Buku cerita bergambar dapat digunakan sebagai media yang baik dalam mengembangkan kemampuan berbicara anak, dengan menggunakan media buku cerita bergambar anak dapat diberikan stimulasi dalam mengembangkan bahasa ekspresif anak khususnya dalam perkembangan bicara.

\section{Penggunaan Media Buku Cerita}

Media merupakan salah satu sumber belajar yang dapat menyalurkan pesan dari pengirim ke penerima. Perbedaan gaya belajar, minat intelegensi, keterbatasan indra, cacat tubuh atau hambatan jarak waktu dan lain-lain, dapat dibantu dengan pemanfaatan media pendidikan. Secara harfiah media berarti perantara atau pengantar. Istilah "media" berasal dari bahasa latin dan merupakan bentuk jamak dari kata "medium" yang secara harfiah berarti tengah, perantara atau pengantar pesan dari pengirim pesan ke penerima pesan (Sadiman, 2014: 6). Selain itu, media dapat dimanfaatkan untuk membantu menyederhanakan proses pembelajaran bahasa dan menyempurnakannya, mengurangi penggunaan bahasa ibu atau bahasa pertama, membangkitkan motivasi atau minat belajar siswa, menjelaskan konsep baru agar siswa dapat memahami tanpa kesulitan dan salah pengertian, menyamakan persepsi, apalagi kalau konsep baru tersebut mempunyai arti lebih dari satu, meningkatkan kualitas pembelajaran dan membuat proses belajar lebih menarik dan interaktif (Suyanto, 2010: 101).

Perkembangan bahasa lisan anak prasekolah tergantung pada banyaknya peluang yang disediakan oleh guru melalui keterlibatan dalam penggunaan bahasa untuk berinteraksi. Mol et al. (2009: 979) menjelaskan tentang penggunaan buku cerita interaktif dapat meningkatkan kemampuan bicara anak, selain itu kualitas buku dan frekuensi dalam penggunaan bukupun menjadi hal yang sangat penting. Salah satu media dalam pembelajaran bagi anak usia dini adalah buku cerita bergambar. Buku cerita bergambar ada yang berupa gambar ilustrasi saja, tetapi kebanyakan buku cerita bergambar merupakan kombinasi dari gambar dan teks. Kombinasi gambar dan teks yang baik dan sesuai sangat diperlukan agar dapat menyampaikan pesan dalam buku tersebut. Buku cerita bergambar mempunyai teks singkat, umumnya terdiri dari 32 halaman yang terdiri dari kata-kata dan gambar yang digabungkan dalam cerita untuk menyampaikan informasi (Tompkins \& Hoskissom, 1995: 43). Cerita untuk anak 
harus memiliki unsur-unsur utama pembangun fiksi seperti tema dan amanat, tokoh, alur, setting, sudut pandang, dan sarana kebahasaan. Unsur-unsur tersebut diolah sedemikian rupa sehingga tetap tercerna oleh anak (Musfiroh, 2005: 38).

Penggunaan buku cerita bergambar merupakan pilihan yang tepat bagi anak. Buku bergambar merupakan buku pertama yang dimiliki oleh anak dalam mengembangkan dan mengeksplorasi dunianya. Scull, et al. (2013: 71) menjelaskan hal penting dalam belajar bahasa adalah membaca buku dan melibatkan anak pada diskusi seputar teks yang dibaca. Melalui buku cerita seperti dapat melihat semua gambar sekaligus, sementara teksnya terlihat sedikit (Mitchell, 2003: 40). Pemaparan yang tidak jauh berbeda disampaikan oleh (Bower, 2014; Biddle, 2014; Mitchell, 2003) yaitu buku cerita bergambar adalah cerita yang didalamnya terdapat kata dan gambar, buku cerita bergambar terdiri dari gambar dan teks yang saling berkaitan. Keduanya saling melengkapi agar dapat menggambarkan sebuah cerita.

Buku cerita bergambar adalah cerita berbentuk buku, terdapat gambar sebagai perwakilan cerita yang saling berkaitan dan juga terdapat tulisan yang dapat mewakili cerita yang ditampilkan oleh gambarnya. Melalui media gambar dapat memperkuat daya ingat serta mempermudah pemahaman dalam memahami isi cerita. Pemaparan tersebut, didukung oleh Toha-sarumpaet (2010: 18) yang menjelaskan bahwa buku cerita bergambar adalah buku yang menyuguhkan cerita dengan menggunakan gambar. Buku cerita bergambar merupakan pilihan yang tepat bagi anak karena buku tersebut menyenangkan bagi anak, buku cerita bergambar didalamnya terdapat beragam desain gambar berwarna yang menarik dan membuat anak menikmati bacaan, pengolahan bahasa dan tema yang bermaknapun menjadi salah satu kemenarikan yang terdapat dalam buku cerita bergambar. Mantei \& Kervin (2014: 76) menjelaskan bahwa buku bergambar merupakan salah satu bentuk seni visual yang penting dan dapat diakses oleh anak karena memberikan kesempatan bagi anak untuk mengeksplorasi pengalaman pribadi dan memahami nilai-nilai yang terkandung dalam keluarga maupun sosial.

Buku cerita merupakan tipe buku yang dipilih oleh kebanyakan orang dewasa untuk dibaca bersama anak-anak (Kotaman \& Balci, 2016: 2). Buku cerita bergambar merupakan buku yang dapat digunakan bagi anak. Buku ini dapat dijadikan sebagai salah satu media perkembangan kemampuan bahasa anak. Reed et al. (2015: 367) menjelaskan bercerita melalui buku cerita bergambar dalam kelompok teman sebaya dapat menstimulasi penalaran bagi anak usia 4,5 sampai 6 tahun. Gambar dalam buku cerita akan lebih efektif bagi anak dalam memahami cerita dibandingkan dengan cerita yang hanya berisi teks saja. Lukens (2003: 40) memaparkan bahwa gambar membuat anak memahami isi dalam satu kali melihat, berbeda dengan tulisan yang perlu dipahami sedikit demi sedikit. Melalui gambar, anak akan diajak atau dituntun untung menghubungkan apa yang dibaca dengan ilustrasi yang ada dalam buku. Gambar dapat menciptakan sebuah suasana jiwa melalui latar gambar atau membuat anak lebih mendalami tentang tokoh dengan melihat rona wajah dan pakainnya. Anak bisa melihat warna pakaian, bentuk wajah tokoh, suasana cerita dan sebagainya dengan bantuan ilustrasi cerita (Lukens, 2003: 45).

Buku cerita memberikan kesempatan pada anak dalam menambah kosakata sehingga anak dapat mengembangkan kemampuan bahasanya. Machado (2013: 252) menjelaskan bahwa guru memahami bahwasanya waktu berdiskusi melalui buku dapat membantu guru agar membangun kosakata, kesadaran phonologi, dan mengembangkan pengenalan huruf. Lenhart, et al. (2017: 1) mengemukakan pendapat serupa, membacakan buku cerita bersama-sama dapat memberikan intervensi dalam pengembangan kosakata. Berdasarkan pemaparan beberapa pendapat yang telah dijelaskan, dapat disimpulkan bahwa buku cerita bergambar adalah buku yang didalamnya terdapat ilustrasi, dimana teks dan gambarnya saling melengkapi untuk dapat menyampaikan sebuah cerita. Unsur utama dari buku cerita adalah cerita dan gambar. Gambar membuat anak memahami isi dalam satu kali melihat, berbeda dengan tulisan yang perlu dipahami sedikit demi sedikit. Melalui gambar, anak akan diajak menghubungkan apa yang dibaca dengan ilustrasi yang ada dalam buku.

\section{METODE PENELITIAN}

Penelitian ini merupakan penelitian kuantitatif dengan menggunakan pendekatan quasieksperimen. Dalam quasi-eksperimen, peneliti menggunakan kelompok eksperimen dan kelompok kontrol, namun tidak secara acak memasukan para partisipan ke dalam dua kelompok tersebut (Cresswell, 2016: 228). Dikatakan eksperimen semu karena tidak semua variabel dapat dikontrol. 
Dalam rancangan penelitian eksperimen tujuan utamanya adalah untuk menguji dampak suatu treatment atau suatu intervensi terhadap hasil penelitian yang dikontrol oleh faktor-faktor lain yang dimungkinkan juga mempengaruhi hasil tersebut (Cresswell, 2016: 208).

Penelitian ini dilakukan untuk mencari pengaruh penggunaan media buku cerita bergambar terhadap kemampuan berbicara anak usia 4-5 tahun. Kelas eksperimen diberikan pembelajaran dengan menggunakan media buku cerita bergambar, sedangkan kelas kontrol dengan menggunakan pembelajaran konvensional. Subjek berjumlah 40 orang anak. Teknik pengumpulan data menggunakan observasi. Teknik analisis data menggunakan uji t-test. Pengerjaan menggunakan program komputer SPSS for Windows versi 16. Lembar observasi tentang kemampuan berbicara terdiri dari: 1) berbicara dengan lancar, 2) menyebutkan nama, 3) menyebutkan alamat, 4) menyebutkan usia, 5) dapat membedakan waktu, 6) menggunakan struktur kalimat lengkap, 7) berbicara 5-6 kata dalam kalimat, 8) menggunakan kata ganti orang, 9) dapat membetulkan kesalahpahaman, dan 10) menyesuaikan topik pembicaraan.

\section{HASIL PENELITIAN DAN PEMBAHASAN}

Data hasil observasi kemampuan berbicara yang dideskripsikan berupa data hasil pretest dan post-test. Data pretest merupakan data hasil observasi kemampuan berbicara pada kelompok eksperimen dan kelompok kontrol sebelum kedua kelompok diberikan perlakuan agar mengetahui kondisi awal kemampuan berbicara anak. Data post-test merupakan data hasil observasi kemampuan berbicara anak pada kelompok eksperimen dan kelompok kontrol setelah kedua kelompok tersebut diberikan perlakuan. Hasil observasi kemampuan berbicara anak dapat dilihat pada tabel.

Tabel 1. Rangkuman Data Observasi Kemampuan Berbicara Anak Pretest dan Post-Test

\begin{tabular}{lllll}
\hline Deskripsi Kemampuan & \multicolumn{2}{c}{ Kelompok Eksperimen } & \multicolumn{2}{c}{ Kelompok kontrol } \\
\cline { 2 - 5 } Berbicara & Pretest & Post-test & Pretest & Post-test \\
\hline Rata-rata & 65.50 & 80.50 & 63.25 & 70.75 \\
\hline Nilai Tertinggi & 75 & 95 & 75 & 85 \\
\hline Nilai Terendah & 50 & 70 & 50 & 60 \\
\hline
\end{tabular}

Berdasarkan tabel 1 dapat disimpulkan bahwa rata-rata nilai pretest pada kelompok eksperimen yaitu 65.50 sedangkan post-test nilai rata-rata meningkat menjadi 80.50. Nilai tertinggi pretest pada kelompok eksperimen 75 dan post-test 95 . Nilai terendah pada kelompok eksperimen pretest sebesar 50 dan post-test 70 . Selanjutnya pada kelompok kontrol, rata-rata nilai pretest sebesar 63.25 sedangkan post-test 70.75 . Nilai tertinggi pretest 75 dan post-test 85 . Nilai terendah pretest 50 serta post-test 60 . Deskripsi data hasil analisis tentang kemampuan berbicara pada kelompok eksperimen dan kelompok kontrol menunjukan bahwa pada saat pretest setiap kelompok memiliki selisih skor yang relatif sama. Selanjutnya diberikan perlakuan yang berbeda untuk kelompok eksperimen dan kelompok kontrol, masing-masing kelompok mendapatkan hasil selisih skor yang berbeda. Pada kelompok eksperimen setelah diberikan perlakuan dengan menggunakan buku cerita bergambar terjadi perubahan yang signifikan pada kemampuan berbicara anak. Untuk kelompok kontrolpun terjadi perubahan, namun tidak signifikan.

Tahapan selanjutnya berupa uji hipotesis, pengujian hipotesis pada penelitian ini menggunakan uji paired sample dan independent sample t-test. Uji paired sample digunakan untuk mengetahui perbedaan antara nilai pretest dan postest kelompok eksperimen sebelum dan sesudah menggunakan media. Uji paired sample digunakan karena sampel yang digunakan sama pada kegiatan pretest dan postest. Selanjutnya dilakukan pengujian menggunakan uji independent sample $t$-test untuk mengetahui perbedaan kelompok eksperimen dan kontrol. Independent sample t-test digunakan sebab sampel yang digunakan berbeda antara kelompok eksperimen dan kelompok kontrol.

Tabel 2. Hasil Perhitungan Paired Sample Kemampuan Berbicara Kelompok Eksperimen

\begin{tabular}{cccc}
\hline Data & Kemampuan & Hasil & Keterangan \\
\hline Pretest-Postest & Berbicara & $0.000<0.05$ & Signifikan \\
\hline
\end{tabular}


Berdasarkan hasil hitung uji t paired sample t-test, nilai signifikansi yang diperoleh pada kemampuan berbicara sebesar 0.000 atau Sig < a $(0.000<0.05)$. Dengan demikian dapat disimpulkan bahwa nilai pretest dan posttest kelas eksperimen untuk kemampuan berbicara memiliki perbedaan signifikan setelah adanya perlakuan menggunakan media buku cerita bergambar.

Tahapan selanjutnya, melaakukan teknik analisis uji-t (independent sample t-test) dihitung dengan menggunakan bantuan program SPSS 16.0 for windows. Kriteria pengambilan keputusan yang digunakan dalam penelitian ini adalah apabila nilai signifikan yang diperoleh lebih kecil dari 0.05 maka $\mathrm{H}_{0}$ ditolak, ini menunjukan terdapat perbedaan yang signifikan antara rerata kelompok eksperimen dan kelompok kontrol. Hasil uji - $\mathrm{t}$ dapat dilihat pada tabel sebagai berikut.

Tabel 3. Hasil Uji-t Independent Sample Pretest dan Posttest Kemampuan Berbicara Kelompok Eksperimen dan Kontrol

\begin{tabular}{lll}
\hline \multicolumn{1}{c}{ Data } & \multicolumn{1}{c}{ Nilai signifikansi } & \multicolumn{1}{c}{ Keterangan } \\
\hline Pretest & $0.340>0.05$ & Tidak Signifikan \\
\hline Posttest & $0.000<0.05$ & Signifikan \\
\hline
\end{tabular}

Berdasarkan rangkuman hasil uji-t independent sample pretest pada kemampuan berbicara anak menunjukan bahwa tidak terdapat perbedaan antara kelompok eksperimen dan kontrol. Hasil perhitungan uji independent sample pretest pada kemampuan berbicara kelompok eksperimen dan kontrol memiliki nilai signifikansi $(0.340>0.05)$. Hasil berbeda yang ditunjukan pada perhitungan uji independent sample posttest terhadap kemampuan berbicara pada kelompok eksperimen dan kelompok kontrol. Hasil rangkuman data posttest kemampuan berbicara dengan menggunakan taraf kesalahan 0,05 maka dapat disimpulkan bahwa $\mathrm{H}_{0}$ ditolak karena diperoleh hasil nilai Sig $<$ a $(0.000<0.05)$. Berdasarkan hasil perhitungan tersebut maka hasil posttest kemampuan berbicara anak menunjukan bahwa terdapat perbedaan antara kelompok eksperimen dan kontrol.

Dalam penelitian ini, kelas A diberikan perlakuan berupa penggunaan buku cerita bergambar, sedangkan di kelas B menggunakan metode konvensional. Hasil penelitian menunjukkan bahwa terdapat pengaruh positif dan signifikan dari penggunaan media buku cerita terhadap kemampuan bicara anak. Hasil tersebut menunjukkan bahwa anak TK yang diberi pembelajaran dengan media buku cerita memiliki kemampuan berbicara yang lebih meningkat dibanding sebelum pembelajaran. Peningkatan kemampuan berbicara pada anak tersebut terjadi karena pembelajaran dengan menggunakan media buku cerita bergambar merupakan salah satu strategi yang dapat digunakan untuk mengembangkan prinsip bermain sambil belajar dan menjadikan anak sebagai pusat dalam pembelajaran dalam pendidikan anak usia dini. Hal ini berarti bahwa proses belajar diperoleh melalui aktivitas atau kegiatan yang dilakukan sendiri atau berkelompok.

Hasil penelitian ini didukung oleh hasil penelitian yang dilakukan oleh Coyne, M., Simmons, D., Kame'enui, E., \& Stoolmiller, M (2004: 12(3), 145-162) menjelaskan hasil temuannya tentang sebuah program intervensi buku cerita dengan instruksi kosakata eksplisit diteliti dalam penelitian eksperimental ini. Intervensi difokuskan pada 34 siswa TK, hasil penelitian menunjukkan siswa dalam kelompok perlakuan dengan penerimaan kosakata rendah, memiliki keuntungan yang lebih besar dalam penguasaan kosakata daripada kelompok kontrol. Temuan ini menunjukkan bahwa bercerita dengan menggunakan buku cerita bergambar secara bersama-sama dengan interfensi kosakata dapat membantu mengurangi atau mencegah pelebaran kesenjangan kosakata antara siswa TK. Selain temuan tersebut, terdapat hasil penelitian lain yang berasal dari Fitriyani \& Joni (2017: 47) yang menjelaskan bahwa kemampuan berbicara anak meningkat melalui kegiatan bercerita menggunakan buku cerita bergambar. Guru mempersiapkan media yang menarik bagi anak. Media yang digunakan dalam penelitian ini adalah buku cerita bergambar. Hasil penelitian menunjukan kemampuan berbicara anak pada Siklus I meningkat menjadi $46.66 \%$ dan pada Siklus II meningkat menjadi $70 \%$. Dengan demikian, dapat disimpulkan bahwa melalui penggunaan buku cerita bergambar dapat meningkatkan kemampuan berbicara anak.

Hasil penelitian yang serupa dijabarkan oleh Reed et al. (2015) yang mengatakan bahwa bercerita melalui buku cerita bergambar dalam kelompok teman sebaya dapat menstimulasi penalaran bagi anak usia 4,5 sampai 6 tahun. Gambar dalam buku cerita akan lebih efektif bagi anak dalam memahami cerita dibandingkan dengan cerita yang hanya berisi teks saja. Pemaparan selanjutnya 
berasal dari Mol et al. (2009) menjelaskan tentang penggunaan buku cerita interaktif dapat meningkatkan kemampuan bicara anak, selain itu kualitas buku dan frekuensi dalam penggunaan bukupun menjadi hal yang sangat penting. Berdasarkan uraian yang telah dipaparkan, maka dapat disimpulkan bahwa penggunaan media buku cerita bergambar berpengaruh signifikan terhadap kemampuan berbicara anak di TK - KB ABA Pringwulung Yogyakarta. Penggunaan media buku cerita bergambar merupakan media yang efektif untuk mengembangkan aspek bahasa khususnya kemampuan berbicara anak.

\section{SIMPULAN DAN SARAN}

Berdasarkan hasil penelitian dan pembahasan yang telah dijelaskan, dapat disimpulkan bahwa terdapat pengaruh signifikan dalam penggunaan media buku cerita bergambar terhadap kemampuan berbicara anak usia 4-5 tahun di TK-ABA Pringwulung Yogyakarta. Hasil ini ditunjukan dari nilai Sig $<$ a $(0.000<0.05)$ dengan perbedaan rerata sebesar 9.750 yang berarti terdapat perbedaan antara kelompok eksperimen dan kelompok kontrol dilihat dari kemampuan berbicara anak. Rekomendasi dalam penelitian ini dapat digunakan bagi orangtua, guru, akademis, dan lingkungan sekitar anak khususnya dalam mengembangkan kemampuan berbicara anak agar dapat distimulasi dengan baik dan optimal.

\section{UCAPAN TERIMAKASIH}

Penelitian dan penyusunan artikel ini tidak terlepas dari bantuan berbagai pihak. Penulis mengucapkan terimakasih kepada:

1. Prof. Suparno, M.Pd, selaku Kapodri Magister Pendidikan Anak Usia Dini, Pascasarjan UNY.

2. Dr.Enny Zubaidah, M.Pd, selaku dosen pembimbing yang telah memberikan bimbingannya.

3. Ibu Sutamini selaku Kepala TK - ABA Pringwulung Yogyakarta beserta para staf pengajar yang telah memberikan ijin dan bantuan penelitian.

4. Universitas Negeri Yogyakarta

\section{DAFTAR PUSTAKA}

Abbas, S. 2006. Pembelajaran Bahasa Indonesia Yang Efektif di Sekolah Dasar. Jakarta: Departemen Pendidikan Nasional.

Biddle, K.A.G., Nevarez, A.G., Henderson, W.J.R., \& Vallero-Kerrick, A. 2014. Early Childhood Education Becoming A Professional. Printed in USA: SAGE Publications, Inc.

Bower, V. 2014. Developing Early Literacy 0 to 8 From Theory to Practice. London: Sage publication L.td.

Coyne, M., Simmons, D. C., Kame'enui, E., \& Stoolmiller, M. 2004. Teaching vocabulary during shared storybook readings: An examination of differential effects. Exceptionality: A Special Education Journal, 12(3), 145-162. http://dx.doi.org/10.1207/s15327035ex1203_3

Cresswell, J. W. 2016. Research Design Pendekatan Metode Kualitatif, Kuantitatif dan Campuran Edisi Keempat. (Terjemahan Achmad Fawaid \& Rianayati K.P). Yogyakarta: Pustaka Pelajar. (edisi asli diterbitkan tahun 2014 oleh SAGE Publication, Inc.)

Efrizal, D. 2012. Improving student's speaking through communicative language. International Journal of Humanities and Social Science, Vol. 2 No.20. p.127-134. Retrieved from http://www.ijhssnet.com.

Fitriyani, N. \& Joni. 2017. Peningkatan kemampuan berbicara anak melalui media cerita bergambar anak kelompok B TK Ayu Smart Kids. PAUD Lectura: Jurnal Pendidikan Anak Usia Dini, Vol 1, No. 1 p39-48. Retrieved from https://journal.unilak.ac.id/index.php/paudlectura/article/view/502/369

Gnjatovic, D. 2015. Stories in different domains of child development. Child care facility University of Malta. Original scientific paper UDK: 37.022. http:// doi.org/10.17810/2015.07, 84-97. 
Pengaruh Penggunaan Buku Cerita Bergambar Terhadap Kemampuan Berbicara Anak

(Eka Mei Ratnasari, Enny Zubaidah)

Hurlock, E. B. 1978. Perkembangan Anak jilid 1. (Terjemahan Meitasari Tjandrasa dan Muslichah Zarkasih). Jakarta: Erlangga. (Edisi asli diterbitkan oleh McGraw-Hill, Inc.)

Hurlock, E. B. 1980. Psikologi Perkembangan: Suatu Pendekatan Sepanjang Rentang Kehidupan. (Terjemahan Shinto B. Adelar dan Sherly Saragih). Jakarta: Erlangga. (Edisi asli diterbitkan oleh McGraw-Hill, Inc.)

Istiyani, D. 2013. Model pembelajaran membaca menulis menghitung (CALISTUNG) pada anak usia dini di kabupaten Pekalongan. Jurnal penelitian vol. 10, No. 1Mei2013. Hlm. 1-18. Retrieved from https://doi.org/10.28918/jupe.v10i1.351

Jalongo, M. R. 2007. Early Childhood Language Arts. Boston: Peaarson Education, Inc.

Johnston, J., \& Halocha, J. 2010. Early Childhood And Primary Education Reading And Reflections. New York: McGraw-Hill.

Kayi, H. 2006. Teaching Speaking: Activities to Promote Speaking In A Second Early Childhood. Art Research and education, 1, Vol. 14 No.8. Retrieved from http://iteslj.org/Articles/KayiTeaching Speaking.html

Kotaman, H., \& Balci, A. 2016. Impact of storybook type on kindergarteners' storybook comprehension. Early Child Development and Care, http://dx.doi.org/10.1080/03004430.2016.1188297

Lenhart, J., Lenhard, W., Vaahtoranta, E., \& Suggate, S. 2017. Incidental vocabulary acquisition from listening to stories : a comparison between read-aloud and free storytelling approaches. Educational Psychology, 1-21. https://doi.org/10.1080/01443410.2017.1363377

Lukens, J. R. 2003. A Critical Handbook of Children's Literature. United States of America: Pearson Education, Inc.

Machado, J. M. 2013. Early Childhood Experiences In Language Arts Early Literacy (10 ${ }^{\text {th }}$ ed). Wadsworth. Cengage Learning.

Mart, C.T. 2012. Developing speaking skills through reading. International Journal of English Linguistics, 10, 2-6. http://dx.doi.org/10.5539/ijel.v2n6p91

Mitchell, D. 2003. Children's Literature An Invitation to The World. Boston: Peaarson Education, Inc.

Mol, S. E., Bus, A. G., \& Jong, M. 2009. Interactive book reading in early education: a tool to stimulate print knowledge as well as oral language. Vol. 79, No. 2, pp. 979-1007. http://www.doi.org/10. 3102/0034654309332561

Musfiroh, T. 2005. Bercerita untuk anak usia dini. Jakarta: Departemen Pendidikan Nasional, Direktorat Jenderal Pendidikan Tinggi, Direktorat Pembinaan Pendidikan Tenaga Kependidikan dan Ketenagaan Perguruan Tinggi.

Mantei, J. \& Kervin, L. 2014. Interpreting the images in a picture book: students make connections to themselves, their lives and experience. English Teaching: Practice and Critique. Vol. 13, No. 2 pp. 76-92. http://education.waikato.ac.nz/research/files/etpc/files/2014v13n2art5.pdf

Nugraha, R. G. A. (2017). Interactive Media Development for Second Grade Elementary Students Thematic Learning Using Adobe Flash CS4 Professional. Scholaria: Jurnal Pendidikan Dan Kebudayaan, 7(2), 94-105.Owens, R. E. Jr. 2012. Langauge development: An introduction ( $8^{\text {th }}$ ed.). New York: Pearson.

Ramirez-Esparza, N., Garcia-Sierra, A., \& Kuhl, P. K. 2014. Look who's talking: Speech style and social context in language input to infants are linked to concurrent and future speech development. Developmental Science, 17: 6, p880-891. http://www.doi.org/10.1111/desc.12172

Reed, H. C., Hurks, P. P. M., Kirschner, P. A., \& Jolles, J. 2015. Preschoolers' causal reasoning during shared picture book storytelling : A cross-case comparison descriptive study. Journal of 
Research in Childhood Education, 29: 367-389, http://www.doi.org /10.1080/02568543.2015.1042126

Ruampol, Y., \& Wasupokin, S. 2014. Development of speaking using folk tales based performance activities for early childhood student. World Academy of Science, Engineering and Technology. International Journal of Humanities and Social Sciences. Vol: 8, No:7, 2014. Retrieved from http://www.scholar.waset.org/1307-6892/9998937

Sadiman, A. S., dkk. 2014. Media Pendidikan Pengertian, Pengembangan, dan Pemanfaatannya. Jakarta: PT. RajaGrafindo Persada.

Scull, J., Louise, P., \& Raban, B. 2013. Young learners: Teachers' questions and prompt as oppurtunities for children's language development. University of Melbourne, Deakin University, and University of Melbourne. Research in early childhood, vol 7 No.1, 69-91. Retrieved from http://research.monash.edu/en/publications/young-learners-teachersquestions-and-prompts-as-opportunities-fo

Suyanto, B. 2010. Metode Penelitian Sosial. Jakarta: Prenada Media Group.

Toha-sarumpaet, R. K. 2010. Pedoman Penelitian Sastra Anak: Edisi Revisi. Jakarta: Buku Obor.

Tompkins, G.E., \& Hoskissons, K. 1995. Language Arts: Content and Teaching Strategies (3 ${ }^{\text {rd }}$ ed.). New York: Mac Millan Publishing Co.

Vygotsky, L. S. 1978. Mind In Society “The Development of Higher Psychological”. USA: Harvard University Press.

Zainatuddar. 2015. Teaching speaking in English by using the picture series technique. English Education Journal (EEJ), 6(4), 443-456, October 2015. Retrieved from http://www.jurnal.unsyiah.ac.id 